\title{
MENGGAGAS PARADIGMA PEMBERANTASAN KORUPSI MELALUI NILAI-NILAI SOSIAL BUDAYA
}

\author{
Eliza Meiyani
}

\begin{abstract}
ABSTRAK
Korupsi di Indonesia sudah memasuki stadium "darurat korupsi”. Stadium ini dikuatkan oleh hasil Survey Masyarakat Internasional yang menempatkan Indonesia sebagai negara terkorup urutan ke 4 di dunia dan nomor 1 di Asia dengan Indeks Persepsi Korupsi (IPK) 9,2. Peringkat ini pada Hakikatnya telah mencederai harkat dan martabat bangsa Indonesia yang tergolong sebagai negara yang berbudaya berdasarkan nilai-nilai Pancasila. Diperlukan upaya untuk menyetop perilaku koruptif dengan membangun paradigma pemberantasannya. Paradigma yang tepat adalah pelembagaan (doble legitimacy) kembali nilai-nilai sosial budaya yang terdapat dalam masyarakat Indonesia. Asumsi ini sangat tepat mengingat perilaku koruptif telah sistemik dalam telah mamasuki sendi-sendi kehidupan masyarakat. Nilai-nilai sosial budaya dalam masyarakat Indonesia sangat potensial untuk memberantas perilaku koruptif. Selama ini paradigma pemberantasan korupsi hanya bertumpu pada paradigma hukum dalam arti memaksimalkan pendekatan undang-undang (law reform) dan kelembagaan (institutions reform) namun hasilnya tidak efektif. Perilaku koruptif semakin mengingat dan terkesan tambal sulam. Sudah saatnya pemberantasan korupsi menggunakan paradigma barn yaitu menggunakan nilai-nilai sosial budaya masyarakat Indonesia. Nilai-nilai sosial budaya masyarakat Indonesia menyimpan potensi yang sangat besar untuk memberantas korupsi karena dengan pelembagaan (double legitimacy) nilai-nilai sosial budaya dapat menjadi instrumen untuk mengontrol perilaku setiap orang untuk tidak koruptif, akan tumbuh budaya saling mengontrol sehingga menutup peluang berperilaku koruptif.

Kata kunci : Korupsi - Nilai-Nilai Sosial Budaya
\end{abstract}

\section{A. PENDAHULUAN}

Salah satu persoalan kritis yang dihadapi bangsa Indonesia adalah negara menjadi sarang korupsi dan terlah memasuki masa "darurat korupsi”. Hal ini dikaitkan oleh hasil Survey Masyarakat internasional yang menempatkan Indonesia dalam urutan kelima negara terkorup dan peringkat pertama di Asia Tenggara. Kondisi ini semakin hari semakin terasa karena perilaku korupsi telah sistemik dalam masyarakat Indonesia. Peringkat sebagai negara terkorup pada hakikatnya telah mencederai martabat bangsa di mata Internasional serta menurunnya image sebagai negara yang bermoral Pancasila. Indikasi tersistemasasinya 
perilaku korupsi dalam masyarakat dapat dirasakan denyutnya karena hampir semua aktivitas kehidupan masyarakat tanpa perilaku koruptif urusan dan kepentingan seseorang sulit didapatkan. Itulah sebabnya mengapa kehidupan masyarakat semakin hari semakin terpuruk karena perilaku koruptif sulit diberantas atau dihilangkan karena telah menjadi perilaku menyimpang yang dilakonkan sebagian besar orang.

Ada sekelompok orang menganggap bahwa perilaku koruptif sudah menjadi kebutuhan dalam aktivitasnya. Aktivitas kehidupan tidak mencapai tujuan tanpa melalui perilaku koruptif. Munculnya kondisi demikian disebabkan karena perilaku koruptif telah menjadi "darah" dan "denyut" dalam aktivitas kehidupan sosial. Seseorang tidak akan mendapatkan sesuatu tanpa perilaku koruptif. Meskipun terdapat resistensi dari kelompok yang kontra namun tidak dihiraukan karena kelompok ini jumlahnya minoritas sehingga kelompok mayoritas yang melanggengkan perilaku koruptif masih banyak dan menduduki posisi strategis dalam masyarakat.

Untuk menghentikan perilaku koruptif tersebut dapat dilakukan dengan berbagai cara agar tidak menyengsarakan bangsa Indonesia secara terus menerus. Upaya pencegahan perilaku koruptif selama ini menggunakan paradigma hukum dalam arti memaksimalkan penegakan hukum melalui ketentuan perundang-undangan. Hasilnya tidak maksimal. Tidak maksimalnya pemberantasan perilaku koruptif karena banyak faktor. Salah satu faktornya yang menurut penulis adalah karena paradigma yang digunakan tidak mengikuti perspektif dasar perilaku korupsi yang sudah sistemik dan telah memasuki sendisendi kehidupan masyarakat dan telah mengacaukan struktur sosial bangsa. Oleh karena itu, paradigma yang tetap untuk memberantas yaitu menggunakan paradigma barn yaitu melalui nilai-nilai sosial budaya masyarakat Indonesia.

Sudah menjadi pengetahuan bersama (common sense) bahwa untuk mengubah sesuatu harus berangkat dari perspektif dasarnya. 
Karena perilaku koruptif sudah sistemik dan telah memasuki sistem sosial, maka pemberantasannya juga dimulai sistem sosial dengan memaksimalkan nilai-nilai sosial budaya sebagai produk budaya masyarakat itu sendiri. Di beberapa daerah di Indonesia banyak nilainilai sosial budaya yang dapat digunakan untuk memberantas perilaku kompetitif. Di Sulawesi Selatan misalnya, ada nilai budaya "SIPAKATAU, SIPAKAINGE, SIPAKALEBBV yang mengandung nilai luhur yang jika diterapkan akan menjadi filter seseorang untuk tidak berperiku koruptif. Selain itu, ada pula nilai "LEMPU”, “ADA TONGENG" dan "GETTENG “ yang merupakan warisan nilai budaya yang dapat mengontrol secara internal setiap orang untuk tidak berperilaku menyimpang. Oleh karena itu dalam tulisan ini akan mengulas paradigma baru pemberantasan korupsi melalui nilainilai sosial budaya agar perilaku koruptif dapat dikikis dalam kehidupan masyarakat Indonesia.
B. PEMBAHASAN

DAN

\section{ANALISIS}

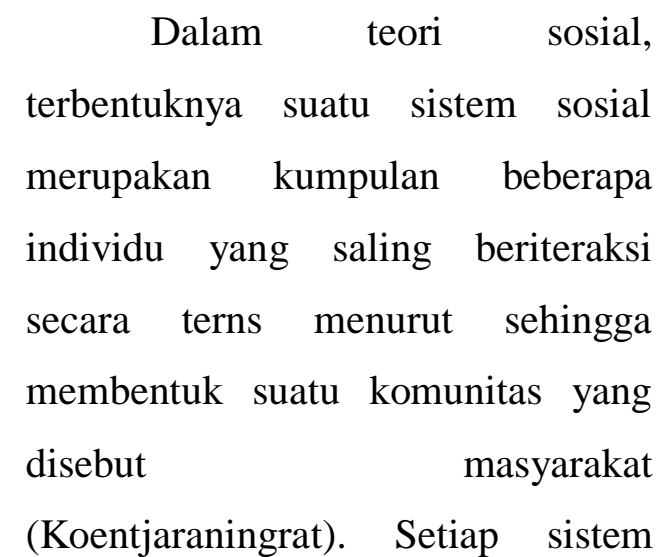
sosial menghasilkan produk yang disebut kebudayaan yang didalamnya tersimpan dengan rapi nilai-nilai budaya yang merupakan kristalisasi gagasan, ide, norma dan nilai-nilai yang dianggap baik oleh masyarakat (Koentjaraningrat,) Nilai-nilai budaya tersebut mengikat setiap komunitas sehingga menjadi acuan untuk berperilaku dalam semua aktivitasnya.

Nilai-nilai, norma-norma merupakan produk suatu kebudayaa. Nilai dan norma tersebut merupakan arsitektur kebudayaan yang merupakan intisari gagasan-gagasan, ide-ide dan harapan-harapan suatu komunitas masyarakat yang menjadi simbol berperilaku dalam kehidupan sehari-hari. Setiap invidu atau orang 
terikat secara ketat dari nilai-nilai dan norma-norma komunitasnya sehingga dengan itu tercipta suatu ketertiban secara terns menerus. Setiap individu dalam masyarakat akan terkontrol oleh nilai-nilai sosial budaya sehingga seseorang tidak sembarang untuk berperilaku apalagi perilaku itu menyimpang dari nilainilai sosial budayanya. meskipun demikian, nilai-nilai sosial budaya tersebut tidak selamanya tegak jika dalam komunitas itu tidak dilembagakan dalam arti dipertahankan, dilestarikan dan ditegakkan dalam praktek kehidupan sehari-hari baik secara pribadi maupun kelompok-kelompok kecil dalam arti keluarga.

Saat ini, perilaku koruptif dalam masyarakat Indonesia sudah memasuki tarap "darurat korupsi" 1. Tanda atau "lonceng" Indonesia telah memasuki darurat korupsi dapat dilihat semakin maraknya perilaku koruptif aparat pemerintah yang tampak dapat dilihat dalam berbagai laporan media cetak dan elektronik. Bahkan, perilaku koruptif ini semakin hari semakin sulit dikendalikan karena lembaga- lembaga penegak hukum mengambil bagian dalam melanggengkan perilaku koruptif ini. Banyak kasus korupsi yang melibatkan oknum aparat pemerintah yang terlibat baik sebagai penerima suap, menerima "gratifkasi” dan sebagainya, yang ikut melanggengkan perilaku koruptif. Itulah sebabnya sehingga perilaku koruptif di Indonesia telah menjadi suatu ideologi tersendiri bagi peminatnya. Telah banyak upaya yang dilakukan oleh pemerintah untuk memberantas korupsi namun tidak pernah berhasil. Selama ini, paradigma yang digunakan pemerintah masih bertumpu pada paradigma hukum dalam arti membuat mengadakan pembaharuan hukum (law reform), pembentukan kelembagaan (komisikomisi) namun semuanya tidak efektif. Upaya ini menurut penulis tidak optimal karena tidak menyentuh akar persoalan muncul perilaku koruptif. Akar persoalan korupsi adalah longgarnya kontrol nilai-nilai dan norma-norma sosial yang ada dalam masyarakat.

Dalam masyarakat di beberapa daerah di Indonesia, nilai- 
nilai sosial budaya tampaknya tidak mendapat perhatian pemerintah untuk dijadikan sebagai sarana untuk memberantas korupsi. Padahal, semua pelaku korupsi (individu) mempakan produk arsitektur kebudayaan yang hidup dan beraktivitas dalam jangkauan dan kontrol nilai-nilai sosial budayanya. Hanya saja, dalam kehidupan kita sehari-hari nilai-nilai sosial budaya daya kontrolnya melonggar. Longgarnya daya kontrol tersebut disebabkan adanya nilai-nilai sosial baru yang menjadi saingan nilai-nilai sosial budaya lama yang tersimpan secara rapi dalam kesadaran setiap pribadi masyarakat Indonesia. Bahkan, dalam masyarakat, beberapa individu sudah meninggalkan nilainilai sosial budayanya dan tidak menjadikannya sebagai instrumen untuk mengontrol perilaku koruptif.

Di beberapa masyarakat Indonesia, terdapat nilai-nilai sosial budaya, seperti, SIRI' di Sulawesi Selatan. Bagi masyarakat Sulawesi Selatan, Siri' merupakan produk budaya Sulawesi Selatan yang sampai sekarang masih ada dan diakui mengandung nilai dan norma yang mengendalikan diri setiap orang Bugis-Makassar. Bahkan, Siri' mengontrol secara internal dan eksternal setiap orang untuk bertindak. Bagi masyarakat Bugis, ada budaya ADA TONGENG, GETTENG DAN LEMPIT yang secara emosional jika disentuh akan bangkit menjadi suatu kekuatan (power) dan menjadi "lokomotif" perubahan (social change) dalam kehidupan yang lebih baik. Mengapa orang Bugis-Makassar tersebar ke luar meninggalkan kampung kalamanya dan umumnya berhasil, itu karena ada dorongan atau kekuatan nilai-nilai sosial budaya yang menjadikan tetap bertahan (survive).

Penerapan atau pelembagaan nilai-nilai sosial budaya tersebut sudah terbukti dalam semua bidang kehidupan. Dalam bidang ekonomi, banyak pedagang Bugis-Makassar berhasil dirantau, seperti, di Malaysia, Singapura, dan sebagainya Dalam bidang politik, banyak pejabat pemerintah pusat menduduki posisi penting dan demikian pula dalam bidang sosial lainnya. Keberhasilan tersebut merupakan manifestasi 
kekuatan nilai-nilai sosial budaya yang dimiliki setiap individu sebagaimana yang diperoleh dari komunitasya. Oleh karena itu, keberhasilan nilai-nilai sosial budaya sebagai "lokomotif" keberhasilan beberapa individu semestinya juga dapat menjadi instrumen dalam memberantas perilaku koruptif dalam masyarakat. Hal ini sangat penting mengingat upaya pemberantasan korupsi yang dilakukan pemerintah sampai saat melalui paradigma hukumnya belum berhasil menurunnya kualitas dan kuantitas perilaku koruptif dalam masyarakat.

\section{Peningkatan Peran Pranata Sosial}

Setiap sistem sosial memiliki pranata-pranata sosial yang menjadi bagian dari struktur sosial yang mendukung keberlangsungan suatu sistem sosial. Pranata-pranata sosial dalam sistem sosial terdiri dari sistem-sistem kekerabatan, sistem kepercayaan, sistem perkawinan simbol-simbol yang mengandung nilai-nilai dan norma-norma yang hidup dalam kesadaran setiap individu (Koentjanmingrat). Semua pranata sosial merupakan produk kebudayaan suatu komunitas dan dipertahankan serta diwariskan secara turun temurun bagi generasinya. Dalam masyarakat Budaya Sulawesi Selatan misalnya, ada pranata sosial yang disebut "To Manurung” yang dipercaya dan diyakini oleh masyarakat BugisMakassar sebagai simbol dan personifikasi dari "sosok" manusia yang bersih, jujur dan bijak yang diutus Tuhan Maha Pencipta yang disebut "dewata". Pranata ini merupakan simbol yang memberikan motivasi bagi orang Bugis-Makassar untuk senantiasa berada dalam posisi sesuai dengan karakter to Manurung tersebut. Melalui karakter "sosok to manurung" itu, setiap orang seharusnya merefleksikan nilai-nilai sosok tersebut untuk senantiasa jujur, bersih dan bijaksana dalam semua perilakunya. Dalam kaitan itu, ketika seseorang mewarisi karakteristik to Manurung akan mengontrol setiap orang untuk selalu dalam posisi sesuai dengan nilai-nilai sosial budaya. Konsekuensinya adalah setiap orang akan saling mengontrol sehingga tercipta suasana saling 
kontrol sehingga ruang atau peluang untuk berperilaku korup akan tertutup.

Selain itu, dalam sistem sosial ada pranata sistem kekerabatan yang didalamnya terdapat nilai -nilai sosial budaya yang dapat menjadi instrumen untuk mencegah orang berperilaku koruptif. Setiap individu dalam masyarakat berasal dari suatu kekerabatan tertentu. Dalam pranata kekerabatan terdapat nilai-nilai kekeluargaan yang dianut dan dipertahankan secara turun-temurun. Bagi orang Bugis-Makassar, dalam sistem kekerabatannya ada yang disebut "abbatireng ana 'arung" atau "ampijangeng to pandrita". Dalam pranata tersebut mengandung nilai sosial budaya yang mewariskan nilai nilai ana'arung yang bernama' maddara takku' yang diartikan 'berdarah putih' .Nilai 'maddara takku' pada hakikatnya adalah nilainilai kesucian yang disimbolkan sebagai 'pntih' dalam arti bersih dan suci. Oleh karena itu, setiap kekerabatan harus mempertahankan nilai kekerabatan dan tidak boleh mencoreng nama kerabat. Dalam kaitan itu, nilai-nilai sosial budaya pranata kekerabatan dapat mendorong orang untuk selalu berperilaku jujur dan bersih karena jika seseorang berperilaku koruptif akan mencoreng atau menurunkan derajat kekerabatannya.

\section{Pemberdayaan}

Lembaga

\section{Budaya}

Salah satu kelemahan atau longgarnya nilai-nilai sosial budaya karena tidak ada lembaga yang menjaga nilai-nilai sosial budaya. Menurunnya semangat untuk mempertahankan atau melembagakan kembali nilai-nilai sosial budaya karena tidak ada lembaga yang khusus menangani ketahanan nilai-nilai sosial budaya. Dalam teori budaya, suatu kebudayaan bam dapat dipertahankan karena adanya pelembagaan dalam arti pemberdayaan pranata-pranata budaya yang telah ada dan dipertahankan melalui gerakan pemberdayaan budaya. Salah satu kelemahan lembaga-lembaga budaya yang di Indonesia adalah tidak adanya kewenangan atau otoritas 
untuk bertindak jika ada pelanggaran nilai-nilai sosial budaya.

\section{Pelembagaan Sanksi Sosial}

Dalam teori sistem disebutkan bahwa setiap sesuatu memiliki sistimnya sendiri- sendiri. Kebudayaan yang di dalamnya tersimpan nilai-nilai dan normanorma sosial juga mempunyai sistem nilai atau sistem norma Dalam sistem nilai atau norma mempunyai komponen-komponen yang merupakan satu kesatuan yang utuh (holistik). Salah satu kendala atau ancaman tidak tegaknya nilai-nilai atau norma-norma sosial budaya adalah tidak ada sanksi yang diberikan kepada pelanggarnya, sanksi dalam rangka penegakan nilai-nilai sosial budaya sangat dibutuhkan mengingat banyaknya pelanggaran nilai-nilai sosial budaya dalam masyarakat yang pada gilirannya akan menyebabkan nilai dan norma tersebut akan kehilangan legitimasinya dalam masyarakat. Dalam catatan sejarah Bugis, misalnya, terdapat kisah seorang hakim La Pagala Nenek Mallomo menjatuhkan sanksi kepada anaknya disebabkan karena ia mencuri alat penggaran tetangganya. penegakan sanksi tersebut mengakibatkan hukum (nilai dan norma sosial) mendapat legitimasi sehingga seseorang tidak akan melakukan perbuatan yang sama (preventif). Selain itu, dalam budaya Bugis juga dikenal sanksi "ripaoppangi tanah" atau dalam budaya Toraja disebut “ma 'rambu langf' yaitu sanksi bempa memotong babi' bagi pelaku pelanggaran. Demikian pula di daerah Wajo, ada sanksi yang disebut " ripomatei” yaitu sanksi berupa denda kepada pelanggarnya. Semua sanksi tersebut dalam perspektif kebudayaan pada hakikatnya merupakan sanksi sosial yang diberikan kepada pelakunya. sanksi sosial tersebut merupakan memproklamasikan kepada masyarakat umum bahwa si pelaku telah merusak tatanan sosial yang dipercaya oleh masyarakat akan mendatangkan bencana. Seseorang yang telah dijatuhi sanksi sosial akan merasa malu dan biasanya akan terhukum di mata orang banyak. Dalam konteks pemberantasan perilaku koruptif, sanksi terhadap 
pelakunya berupa sanksi sosial sudah saatnya digunakan bagi mereka yang berperilaku koruptif agar semua orang mengetahui bahwa si pelaku telah melakukan perbuatan yang bertentangan dengan nilai-nilai sosial yang berlaku.

Sanksi sosial yang perlu diberikan kepada mereka yang berperilaku koruptif adalah dikucilkan dari masyarakat atau diasingkan dari masyarakat sebagaimana yang dilakukan oleh masyarakat di Perancis dan Rusia. Di Prancis, pelaku korupsi dibenci oleh masyarakat dan di Rusia pelakunya dibuang ke Siberia. Di Indonesia, melalui nilai-nilai budaya sanksi sosial juga dapat dilakukan, hanya saja di Indonesia perlu ada komitmen bahwa pelaku koruptif haras diberi sanksi sosial meskipun sanksi ini tidak diatur dalam ketentuan perundang-undangan. Oleh karena itu, penerapan sanksi sosial sudah saatnya menjadi salah satu paradigma baru salam memberantas perilaku korupsi di Indonesia. Semua daerah di Indonesia pasti memiliki sistem sanksi yang berbeda menurut nilai-nilai budayanya dan masih mendapat legitimasi dari komunitasnya.

\section{Menerapkan konsep Reward dan Punisment}

Dalam budaya Masyarakat Sulawesi Selatan dikenal isitilah "Mali Sipareppe, tuo sipatokong" atau dalam bahasa yang lain disebut "SIPAKALEBBI, SIPAKARAJA DAN SIPAKATAU". Dalam perspektif budaya, nilai-nilai sosial budaya tersebut mengandung suatu pesan bahwa dalam kehidupan sosial seseorang harus mampu saling menghargai, menasehati dan saling membesarkan. Lawan dari nilai ini adalah saling menyikut, saling mematikan dan saling mencela.

Saat ini nilai-nilai sosial budaya tersebut kurang diterapkan oleh karena adanya pengaruh nilai individualisme yang senantiasa dipromosikan oleh dunia barat. Konsep pembangunan masyarakat selalu menggunakan konsep barat yang dianggap lebih maju dan melupakan nilai-nilai sosial budaya kita. Mengapa bangsa Indonesia semakin hari semakin terpuruk dalam semua dimensi kehidupan 
kuncinya adalah kita telah tercabut atau dicabut dari akar budaya bangsa Indonesia. Sudah saatnya dalam kehidupan kita memberikan penghargaan kepada mereka yang terus-menerus mempertahankan nilai-nilai sosial budaya dalam bentuk penghargaan (reward) dan memberikan hukum (punishmet) kepada mereka yang melanggar nilai-nilai sosial budaya kita.

Fenomena dalam masyarakat kita, tidak ada bedanya mereka yang konsisten dengan yang tidak konsisten dengan nilai-nilai sosial budaya. Tidak ada perbedaan orang yang perilaku korup dengan yang tidak berperilaku korup. Mereka sama-sama dihormati dalam kehidupan sosial. Ini menunjukkan bahwa dalam masyarakat kita gejala bahwa perilaku koruptif menjadi perilaku benar yang walaupun secara idealnya bertentangan dengan nilainilai sosial budaya bangsa. Kecenderungan ini mesti dihentikan mengingat perilaku korup di manapun merupakan musuh bersama (common enemy). Munculnya gerakan anti korupsi sudah dilakukan pada skala nasional dan internasional. Bahkan, masyarakat internasional mengutuk korupsi sebagai extra ordinary crimekejahatan luar biasa. Penetapan status korupsi sebagai kejahatan luar biasa karena korupsi merupakan kejahatan konstitusional, menghancurkan sendi dan moralitas bangsa, mencoreng martabat bangsa, serta menghambat laju pembangunan.

Oleh sebab itu, diperlukan paradigma memberantas korupsi dengan memberikan hukuman kepada perilaku korup dan memberikan penghargaan kepada mereka yang konsisten mempertahankan nilai-nilai sosial budaya Hal ini perlu dilakukan agar ada perbedaan jelas dan tegas sehingga dapat mengembalikan fungsi-fungsi sosial nilai-nilai sosial budaya dalam masyarakat.

\section{PENUTUP}

Perilaku koruptif yang menggejala di masyarakat Indonesia sebagai penyakit dapat diberikan solusi pemberantasan dan penanganannya melalui gagasan pemberantasan melalui penerapan 
nilai-nilai sosial budaya, dalam hal ini adalah nilai-nilai lokal Bugis seperti “Ada Tongeng, Getteng, Lempu" yang dijiwai oleh

"Sipakalebbi, Sipakaraja, dan

Sipakatau"

DAFTAR PUSTAKA

Salle, Aminuddin. 2009 